\title{
Value Creation in Agri-Food Products in Emerging Economies: Evidences from Angola
}

\author{
Alvaro Dias ${ }^{1 *}$, Joffrana Xavier Oliveira ${ }^{2}$, Beatriz Corchuelo Martinez-Azua ${ }^{3}$, Pedro Eugenio \\ Lopez-Salazar ${ }^{3}$
}

${ }^{1}$ Universidade Lusofona and ISCTE-IUL, Portugal.

${ }^{2}$ Instituto Superior de Gestao, Angola.

${ }^{3}$ Universidad de Extremadura, Spain.

\section{*Corresponding Author: Alvaro Dias}

Abstract: Local products are underappreciated by Angolan consumers. However, there are some pioneer cases of local agri-food products that are valuing their producers. In as far as studies related to the creation of local value in Angola go; there is still a scarcity of literature. In this sense, the objective of this research is to shed light on what is being done in the field of value creation in local agri-food products. This study is anchored on extensive field research and comparative case studies of three Angolan agri-food products. In-depth interviews to producers and retailers and field and product analysis were used to compare the strategies of value creation. This article provides an operationalization of a model to assess value creation strategies on local agri-food products in emerging economies. We also provide empirical evidence from Angola, a country lacking scholar research. Firms show some efforts to create value in the "information" dimension, materialized through careful packaging and labeling, conveying of a set of informative elements that strengthen local product benefits. The progress in the remaining four value creation sources is yet unclear. The 'product' benefits from more advanced production systems and customer relationships revealed a strong weakness due to the nonexistence of consistent work with the distribution channels.

Keywords: Angola, agri-food; Value creation, Local products; Sources of value; Emerging economies; Africa.

JEL: M31; M37; Q13; O55

Article Received: 08 August 2019

Revised: 13 August 2019

Accepted: 24 August 2019

\section{Introduction}

Given that value creation can be understood from various points of view (business valuation, accounting, economics, etc.), in this article we will limit ourselves to the creation of value for the clients of agri-food products. The value creation for the customer is a concept related to customer perception. As such it can be defined by the equation: benefits perceived by the client fewer costs perceived by the client (Day [1]; Lai [2]).

The greater the result of the equation, the more the client will perceive value. The creation of value is reflected in the worth that the products or services convey to customers, thus it will be positive when there is an acknowledgment of their profits or privileges, of their peculiarity or their characteristics.
Contrastingly, it will be negative when there is an additional effort to acquire the product or when costs are high compared to what is paid (Gale [3]; Heard, [4]; Zeithaml [5]).

The way in which clients perceive benefits (and costs) is idiosyncratic, given that those perceptions result from a complex mental equation, from the person's own cultural and social evolution, which occurs in unique contexts. Another factor is the consumer's knowledge capacities to evaluate what they are willing to buy, Lepak, Smith, and Taylor [6].

The markets evolution has been regulated by several situations of disruption that were embodied in three revolutions, over time: Agricultural Revolution, Industrial Revolution and Information Revolution. 
Lee, Olson, and Trimi [7] claim that a new revolution is underway, the fourth, which reveals itself through innovation.

The fourth revolution, therefore, is based on innovation, and innovation plays a key role in value creation. In a process of value creation, both parties involved in a transaction process win, first the company will be satisfied by the positive acceptance of the value created by the customer and, second, customers will be satisfied with the value created by the product Gupta and Govindarajan [8], in addition, Lee, et al. [7] further emphasize the importance of innovation - value creation is the undeniable key to development and competitive stimulation.

In developed markets there is a clear appreciation of local products by consumers, however, in developing countries, this seldom happens. For example, a study carried out by Batra, et al. [9] pointed out that brands perceived as foreign are preferred over local brands in developing countries.

Angolan local products endure the same problem and are underappreciated by Angolan consumers. Additionally, the Angolan industry has been concentrated in a mono-dependence of petroleum, relying upon the importation of foreign products. With the crisis of currency, followed by an economic crisis, the political power and the business community has sought to invest in the diversification of the economy, showing a significant delay in the development of competitiveness of Angolan products and, in particular, agricultural products, suffering from low value added.

Furthermore, Angola has been the object of very few academic studies, especially in the area of the marketing of agricultural products and the way in which producers are creating value to increase their competitiveness in a market accustomed to having imported products of superior quality. To our best knowledge there's no empirical research on this subject.

However, there are some pioneer cases of local agri-food products that are valuing their producers. In this sense, the objective of this research is to shed light on what is being done in the field of value creation in local agri-food products.
This article is structured as follows. On the next section we discuss the theoretical framework and the on-going discussion about 'value'. Methodology follows by presenting the empirical approach that underlies this research. On the following section results are discussed. Finally, the conclusions, implications and limitations and further research are presented.

\section{Theoretical Framework}

\section{Value Creation}

In this section we will briefly discuss some topics concerning the concept of value creation. As mentioned previously, the value creation considered in this research is focused on the customer by Las Casas [10], which also has diverse orderings. Bowman and Ambrosini [11] proposed (1) value of use.

Refers to the specific quality of a product or service perceived by clients in relation to their needs. It consists on a perception by the consumer of the degree of satisfaction of their own needs provided by a product or service. (2) Exchange value, which corresponds to the amount paid by the customer to the seller for the value of usage of a product or service.

This amount corresponds to an effort that can be translated into money, time, distance, etc. The perception of a client is influenced by a series of factors that make each individual's response unique. First, the cultural, social and family context of each person influences individual beliefs and how they develop over time. Cultural factors can manifest themselves in different ways in two different people, seeing that each one grew up in unique family environments (Lai [2]).

Thus, the perspective of creating value to a client "focuses on what the customer does with services and products in their sphere of life" (Gummerus, [12], p.6). Second, in a closer sphere to the individual, personal factors must also be taken into consideration and are directly related to the needs of each person, although conditioned by the personality of each individual (Oliver, [13]).

Third, consumption factors refer to subjective beliefs about the desired ways to achieve personal values, which means that each individual achieves his/her, goals differently (Oliver, [13]). 
For example, when traveling, an individual seeks to satisfy his/her fun and experience needs by acquiring a specific set of products and services (suitcases, food, insurance, etc.) that allow him/her to accomplish his/her cultural and personal goals.

Considering the value creation through products and their importance in the competitiveness of a company, Cooper [14] states that producers who do not risk the value of creation for the customer in the different domains, show a lesser market as compared to those who bet on creating or innovating, as they tend to be better placed to offer value.

\section{Creation of Value in Agri-Food Products}

Woodruff (1997) contends that the perception and evaluation of the components of the product, as well as their added value and negative effects on the use of the product, can be estimated by the customer before or postproduction. These assessments can be made influenced by marketing strategies. Being such evaluations positive, there is the value creation for the client, as maintained by Slater [15] and Cooper [14].

Particularly traditional food products are an important element of a country's culture, identity and heritage, contributing to the development and sustainability of rural areas and protecting them from depopulation. However, this statement on the market implies a substantial commitment to product differentiation, both at the level of production and processing. This bet is reflected on a wide variety in the choice of food products for consumers. Traditional food products are usually associated by consumers with regional identity and sensory quality (Guerrero, et al., [16]).

In developed countries, traditional foods are an important element of heritage, representing a very significant source of revenue in many regions. At the same time, the importance of the local food industry has grown over the last decade (Rudawska [17]). The creation of value in agri-food products, according to Zuin [5] is associated to processing, especially with regards to the extension of the life of the product itself, innovation in the way the product is presented to the customer (e.g. packaging) and consumer convenience.
For these authors, image is also relevant, as well as the existence of transparent and interactive communication with the client. Valuation of local food products is generally associated with greater knowledge of technology or production methods, freshness of products, the natural factor and geographical origin (Gellynck, et al., [18]).

In fact, production methods and origin are very important, not only because geographical proximity is a preponderant and efficient factor for sustainable value creation, Schmitz and Nadvi [19], but also consumers tend to associate better quality with traditional products, also derived from a kind of nostalgia that takes them back to their roots (Gellynck, et al., [18]). Furthermore, Zuin [5] add that it is important to consider the fact that those are generally products from rural areas. This partially means that value creation is not taking large strides because there is certain orthodoxy on the part of human capital, traditionalism that goes from the manner of production to the capacity to understand the need for value creation, passing through tradition/personal culture. With this situation in mind, the companies that are better structured and have vision of the future are the ones that win.

Malafaia, et al. [20] claim that this sector has a different importance compared to others, because the raw material is also different from the others. Resquier-Dejardins et al. [21] identifies some significant elements for the acceptance by customers: cultural identity, origin of the environment, traditions, territorial situations, until the creation of a product quality convention, which aggregates a certain singularity to all products of origin. Traditional food together with the culinary heritage and geographic origin of the product can play a significant role in the market as these are increasingly sought after by consumers.

Traditional food is an expression of culture, identity, history, and lifestyle (Kuhne, et al., [22]). This opens new growth opportunities for small and medium-sized enterprises (SMEs), which make up the bulk of the industry, especially traditional food products (Guerrero, et al., [16]), particularly if they adopt appropriate marketing strategies (Rudawska, [17]). 
The creation of value in agri-food products, as mentioned, can be achieved through innovation, but at the same time, it is necessary to preserve the identity, culture and history that are embedded in them. Mossberg [23] further argues that the creation and delivery of value for the client requires the conjugation of the place where the product is bought or consumed and the quality of the product.

\section{Element of Value Creation}

Park, Jawarski and Macinnis [24] consider that value creation is based on three pillars: symbolic value, functional value, and experiential value. The first considers that customers expect to achieve a certain degree of personal or even social significance. The functional value corresponds to characteristics inherent to the product itself, namely that they are practical and excellent in their functions. Finally, the experiential value revives emotional standards of comfort, security, romance, and even some dismay or fear. These characteristics open doors for producers to bet on innovation and creativity, so value creation goes through different paths, not only via industrialization (agribusiness) but also fostering gastronomy.

In this research, value creation will be considered through its various sources. The following table looks at customer value sources, which Smith and Colgate [25] say are factors that outweigh others in creating and delivering value to customers.

Table 1: Theoretical framework of sources of value

\begin{tabular}{|c|c|}
\hline Sources of value & Definition \\
\hline Information & $\begin{array}{l}\text { This is considered a key point, because it attracts } \\
\text { the customer to the product, showing the added } \\
\text { value of the product through advertising, } \\
\text { packaging, label, list of instructions, for these help } \\
\text { clients to better know the product and to take } \\
\text { decisions. } \\
\text { "Information is the key to success." }\end{array}$ \\
\hline Product & $\begin{array}{l}\text { When we refer to the product, we mean its } \\
\text { innovation because, whether it already exists or } \\
\text { not, it lacks market research, research and } \\
\text { development about it and its manufacture, to also } \\
\text { decrease investment risk, so that it may better } \\
\text { correspond to the market/customer expectations, } \\
\text { because creations are not perfect, there are gaps } \\
\text { and there is always something to be improved. }\end{array}$ \\
\hline Interaction between clients and employees & $\begin{array}{l}\text { Here we focus on quality of, pre and post-sale, also } \\
\text { of client assistance, showing not only the quality of } \\
\text { the product, but also of those who produce it or } \\
\text { resell it, creating and transmitting "trust". }\end{array}$ \\
\hline Purchase and consumption environment & $\begin{array}{l}\text { These are physical spaces, or not (websites), where } \\
\text { a client can find the product and, as said } \\
\text { previously, it is essential that when the client } \\
\text { comes into contact with the product he/she will not } \\
\text { just simply analyze the product, he/she will } \\
\text { similarly analyze the whole of the environment } \\
\text { around the product, what it has in normal or } \\
\text { higher standards will contribute positively to the } \\
\text { purchase and consumption process. }\end{array}$ \\
\hline Transfer of ownership & $\begin{array}{l}\text { The issue of transfer of ownership is self-defining; } \\
\text { however, we will present two examples that make } \\
\text { such transfer explicit: the accountancy issue } \\
\text { (collection and payment), delivery/dispatch in the } \\
\text { right time, tracking of the goods). }\end{array}$ \\
\hline
\end{tabular}




\section{Methodology}

In order to achieve the objective of this research, a comparative was conducted based on an extensive field research erected on Smith and Colgate's [25] value sources. In this sense, we selected three Angolan products which have come to stand out by the appreciation of their offer. We should point out that there are more companies that have also been making efforts to create value but, on interpreting the literature used for this research, we considered that the three referred to cases are better framed in terms of value creation in local products in Angola. First, the data was collected by observing activities developed by the three manufacturers and by analyzing the products they offered. Second, after compiling product information and observing them on several retailers, we conducted in-depth interviews to the firm's managers. For the interviews a semi-structured script was created based on table 1 assumptions. The first case was Moxico Honey. Moxico is an Angolan province with a vast agricultural history and has a very big potential in the production of honey, so much so that producers are investing on the value creation for the product, through industrial processing, but always trying to preserve its natural characteristics, even when reaching the export level. The honey studied in this research is the one produced by CAOPA - Cooperativa Agropecuária, Pesca e Agricultura (Livestock, Fisheries and Agriculture Cooperative).

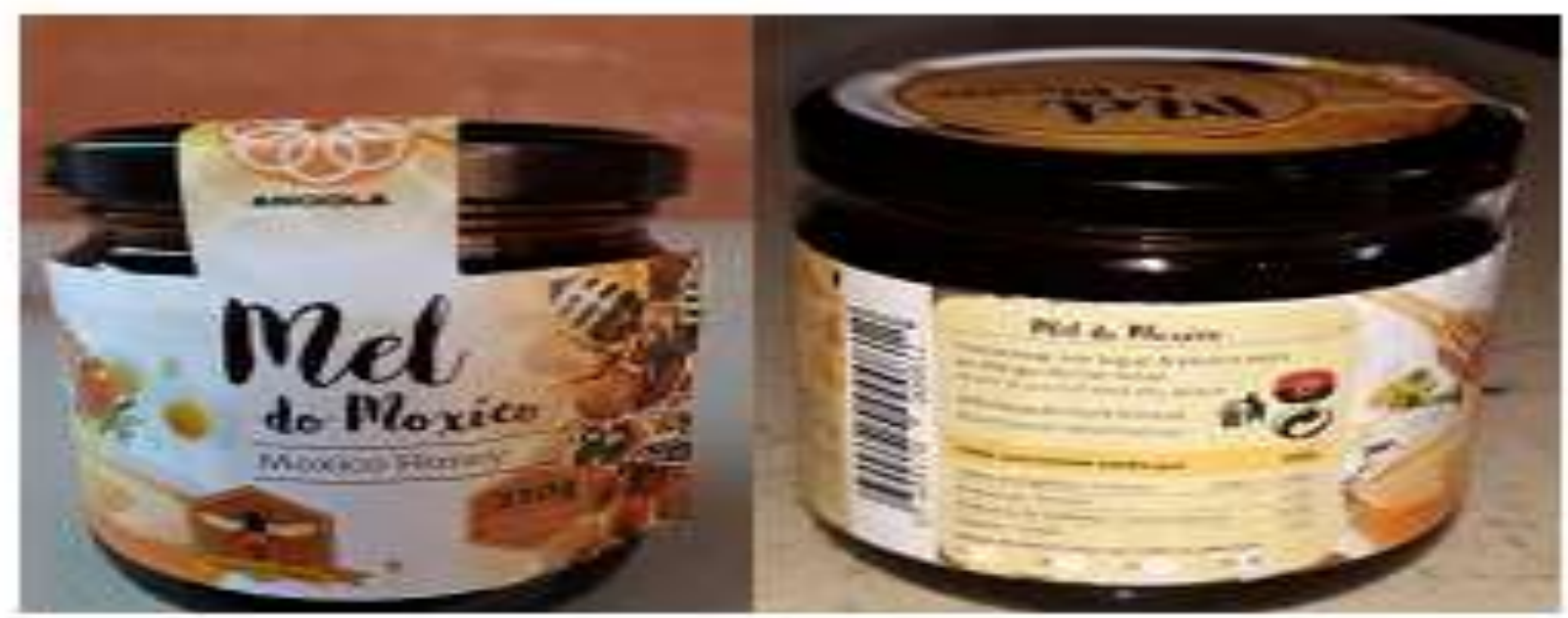

Source: The authors

Fig. 1: Honey from Móxico

Café (coffee) da Gabela was the second case. Angolan coffee is one of the products that have high international reputation. Because of the long period of war, production declined significantly. After 2002 (beginning of the peace period in Angola), production was resumed on a larger scale, but with little added value. Angolan coffee brands have had little significance in their own country, which is why we chose this brand, because it is the one that has stood out the most and is being produced by Kapilongo and JMC.

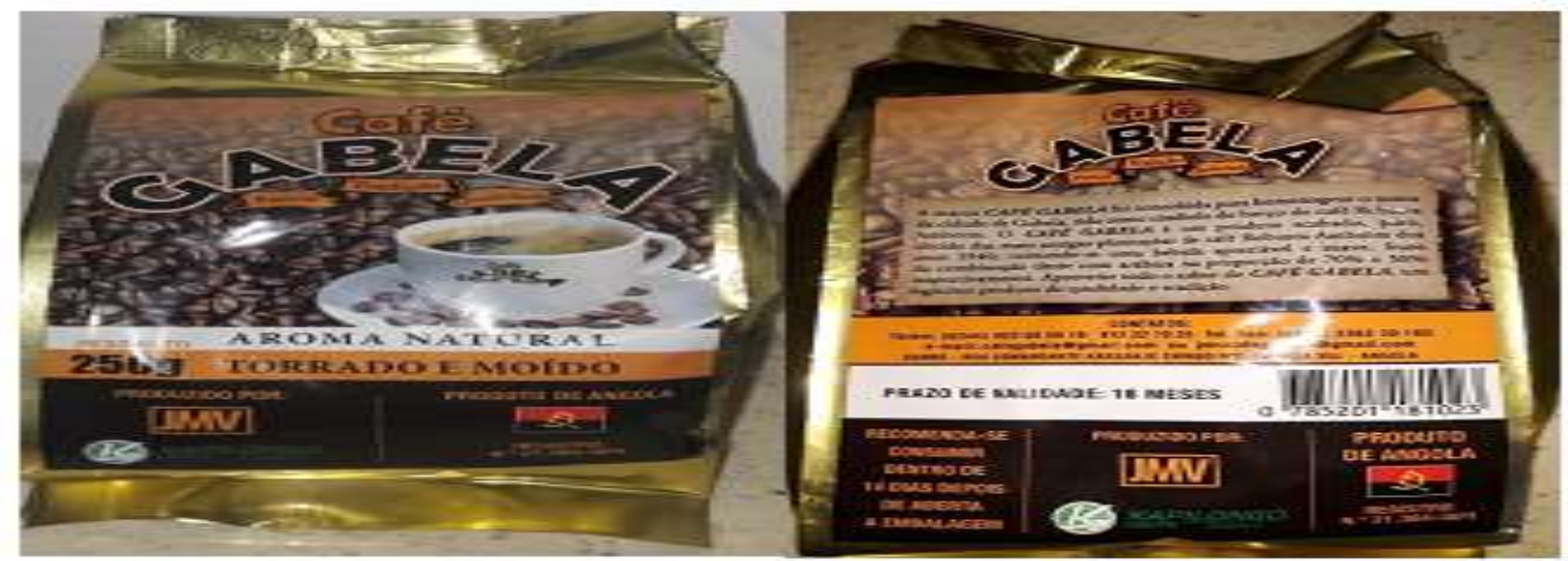

Source: The authors

Fig. 2: Coffee from Gabela 
The third case was the products of the Lactiangol Company, because they offer a wide variety or agricultural products that have stood out for their value creation: juices, yoghurts, and others. This is an interesting case because there is a clear $100 \%$ bet on what is Angolan by Lactiangol.

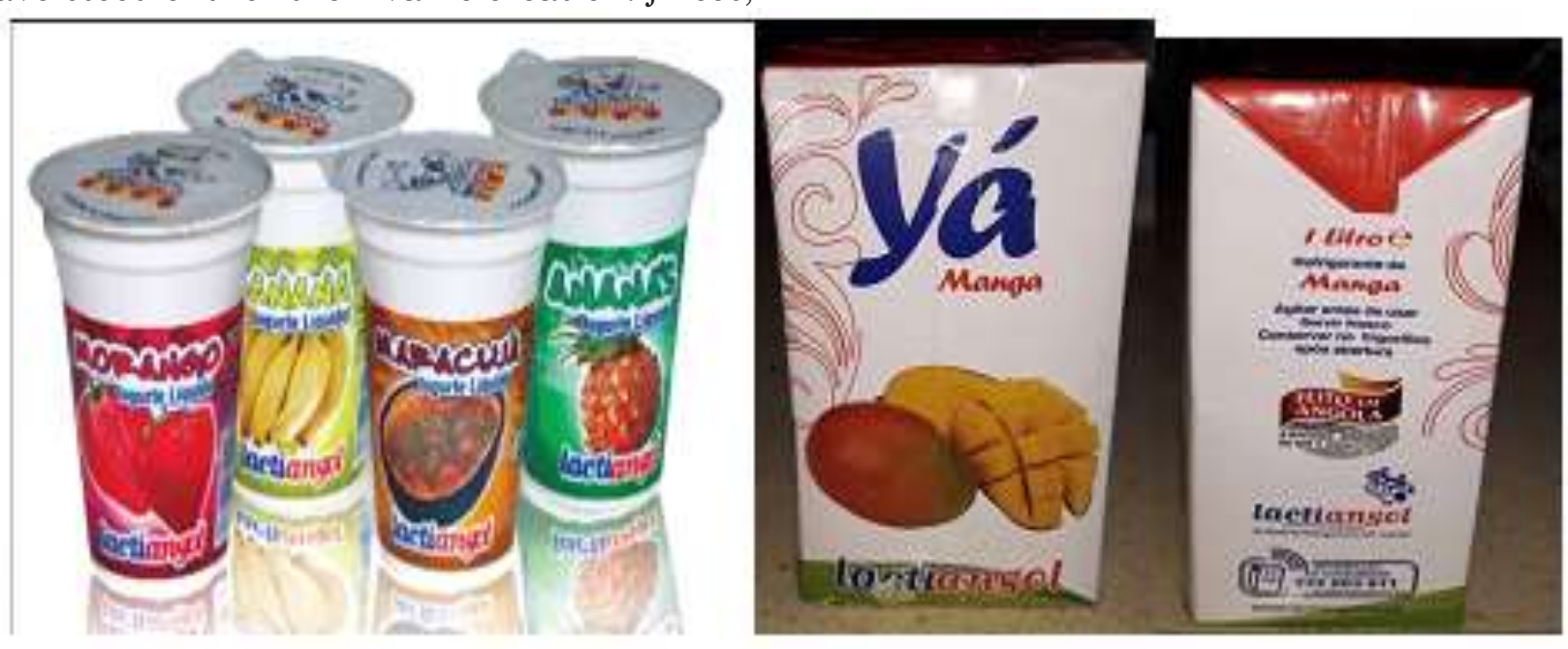

\section{Results}

After the in-depth interviews and field collection, data was treated according to the approach proposed by Smith and Colgate
[25]. In order to simplify the comparative analysis and discussion, the results are arranged it in the following Tables.

\section{Table 2: Value Source Information}

\begin{tabular}{|c|c|c|c|}
\hline \multicolumn{4}{|c|}{ Value Source: Information } \\
\hline subclasses & Case 1 & Case 2 & Case 3 \\
\hline Publicity & $\begin{array}{l}\text { This one's publicity is } \\
\text { of a low character, } \\
\text { given that } \\
\text { advertisements and } \\
\text { propaganda is more } \\
\text { on the old word of } \\
\text { mouth fashion. Its } \\
\text { creation of value to } \\
\text { the publicity is done } \\
\text { in a strand that } \\
\text { points far more } \\
\text { outward and very } \\
\text { little to the national } \\
\text { market }\end{array}$ & $\begin{array}{l}\text { This one has medium } \\
\text { publicity of the } \\
\text { products, which varies } \\
\text { from advertising } \\
\text { billboards to } \\
\text { advertisements on } \\
\text { TV, because it also } \\
\text { has a greater range of } \\
\text { consumers than the } \\
\text { previous one }\end{array}$ & $\begin{array}{l}\text { In this one the company } \\
\text { bets heavily on advertising } \\
\text { because, between the three, } \\
\text { this one is longer in } \\
\text { existence and the } \\
\text { advertisements meet the } \\
\text { expectations of people of all } \\
\text { social classes and exceeds } \\
\text { the country's borders. }\end{array}$ \\
\hline Packaging & $\begin{array}{l}\text { It has simple and } \\
\text { common packaging in } \\
\text { the market for the } \\
\text { product that adds } \\
\text { value, simple, easy, } \\
\text { but not very practical } \\
\text { for a honey package }\end{array}$ & $\begin{array}{l}\text { Simple, practical and } \\
\text { not standardized } \\
\text { (various formats). } \\
\text { Contains strong } \\
\text { colours and images } \\
\text { that have an affect on } \\
\text { the client. }\end{array}$ & $\begin{array}{l}\text { These are standardized and, } \\
\text { in addition to the brand of } \\
\text { the company, they show the } \\
\text { brand Ya in the product } \\
\text { packaging, however, the } \\
\text { package of the yoghurts has } \\
\text { only } 1 \text { name, they're equally } \\
\text { conventional to those of the } \\
\text { market. }\end{array}$ \\
\hline Labels & $\begin{array}{c}\text { Displays preservation } \\
\text { information, } \\
\text { nutritional value, } \\
\text { specifies that it is } \\
\text { natural bee honey } \\
\text { from Moxico/Angola, } \\
\text { contacts of the } \\
\text { company and the }\end{array}$ & $\begin{array}{l}\text { Shows the history of } \\
\text { the product and the } \\
\text { reason for its name, } \\
\text { recommendations for } \\
\text { use, sell by date, } \\
\text { company contacts and } \\
\text { the seal that it is } \\
100 \% \text { produced in }\end{array}$ & $\begin{array}{l}\text { Stamped on them is the } \\
\text { information that they are } \\
100 \% \text { produced in Angola, } \\
\text { besides nutritional, of use } \\
\text { and the contacts of the } \\
\text { company. }\end{array}$ \\
\hline
\end{tabular}




\begin{tabular}{|c|c|c|c|}
\hline & Angolan seal & Angola & \\
\hline & $\begin{array}{c}\text { This component is } \\
\text { low, from } \\
\text { participation to } \\
\text { promotion. }\end{array}$ & $\begin{array}{c}\text { This component is } \\
\text { weak, but there are } \\
\text { records of } \\
\text { participation in fairs, } \\
\text { meetings, as a means } \\
\text { for further } \\
\text { pents }\end{array}$ & $\begin{array}{c}\text { This one has the } \\
\text { in fairs and of sponsoring } \\
\text { events, which diffuses } \\
\text { information about their } \\
\text { products }\end{array}$ \\
\end{tabular}

Table 3: Source of Product Value

\begin{tabular}{|c|c|c|c|}
\hline \multicolumn{4}{|c|}{ Source of Value: Product } \\
\hline Subclasses & Case 1 & Case 2 & Case 3 \\
\hline $\begin{array}{l}\text { Own store (physical } \\
\text { or not) or Highlights } \\
\text { in the sales space }\end{array}$ & $\begin{array}{l}\text { There is no store of } \\
\text { its own, it has an } \\
\text { acceptable } \\
\text { prominence, but } \\
\text { without much } \\
\text { eminence. }\end{array}$ & $\begin{array}{l}\text { It does not have a } \\
\text { selling point of its } \\
\text { own, such as } \\
\text { "Nespresso", but in } \\
\text { some distribution } \\
\text { channels it holds a } \\
\text { privileged position. }\end{array}$ & $\begin{array}{c}\text { It has physical and virtual } \\
\text { space, but the products are also } \\
\text { commercialized in various } \\
\text { points of purchase. }\end{array}$ \\
\hline Product Status & $\begin{array}{c}\text { Fresh and appealing } \\
\text { to the client }\end{array}$ & Fresh, smell, quality. & Fresh, good aspect. \\
\hline Innovation & $\begin{array}{l}\text { Change from rustic } \\
\text { packaging to a more } \\
\text { sophisticated one, } \\
\text { and durability of the } \\
\text { product. }\end{array}$ & $\begin{array}{l}\text { In the presentation of } \\
\text { berries already } \\
\text { refined and ready to } \\
\text { be used, in the } \\
\text { package }\end{array}$ & $\begin{array}{l}\text { Brings more and more the } \\
\text { original fruit flavour in both } \\
\text { juices and yoghurts }\end{array}$ \\
\hline Production research & $\begin{array}{l}\text { Improvement in } \\
\text { conservation, } \\
\text { research also in the } \\
\text { concept price and } \\
\text { quality and greater } \\
\text { expansion in the } \\
\text { market }\end{array}$ & $\begin{array}{c}\text { Research on the } \\
\text { simplification of } \\
\text { practical use and } \\
\text { quality and of } \\
\text { entering the world of } \\
\text { capsules and of } \\
\text { studies combining the } \\
\text { cost-benefit factor. }\end{array}$ & $\begin{array}{l}\text { Better fit of the product to the } \\
\text { packaging and to customer } \\
\text { needs supporting product } \\
\text { innovation in this and other } \\
\text { cases. }\end{array}$ \\
\hline
\end{tabular}

Table 4: Interaction between clients and employees

\begin{tabular}{|c|c|c|c|}
\hline \multicolumn{4}{|c|}{ Value source: interaction between clients and employees } \\
\hline subclasses & Case 1 & Case 2 & Case 3 \\
\hline Store Interaction & $\begin{array}{l}\text { Good, from the outset, } \\
\text { they are easy products } \\
\text { and do not require much } \\
\text { explanation to attract the } \\
\text { customer only to that } \\
\text { brand, and not to } \\
\text { competing ones. }\end{array}$ & $\begin{array}{l}\text { Good, from the outset, } \\
\text { they are easy products } \\
\text { and do not require much } \\
\text { explanation to attract the } \\
\text { customer only to that } \\
\text { brand, and not to } \\
\text { competing ones. }\end{array}$ & $\begin{array}{l}\text { This one has the } \\
\text { particularity of the } \\
\text { brand already } \\
\text { being known to the } \\
\text { customers and } \\
\text { conveys some } \\
\text { confidence, and the } \\
\text { service provided in } \\
\text { stores is not } \\
\text { something very } \\
\text { homogenous. }\end{array}$ \\
\hline Pre-sales service & $\begin{array}{l}\text { This point refers us to } \\
\text { advertising and this is a } \\
\text { weakness they have. }\end{array}$ & $\begin{array}{l}\text { This point refers us to } \\
\text { advertising and this is a } \\
\text { weakness they have. }\end{array}$ & $\begin{array}{l}\text { When this one } \\
\text { decides to launch a } \\
\text { new product, it } \\
\text { usually has this } \\
\text { service to make the } \\
\text { product known to } \\
\text { their public. }\end{array}$ \\
\hline
\end{tabular}




\begin{tabular}{|c|c|c|c|}
\hline After sales service & $\begin{array}{l}\text { There is an after sales } \\
\text { service that goes beyond } \\
\text { the point of purchase even } \\
\text { by the brand itself that } \\
\text { makes their contacts } \\
\text { available on the label of } \\
\text { the product. }\end{array}$ & $\begin{array}{l}\text { There is an after sales } \\
\text { service that goes beyond } \\
\text { the point of purchase even } \\
\text { by the brand itself that } \\
\text { makes their contacts } \\
\text { available on the label of } \\
\text { the product. }\end{array}$ & $\begin{array}{l}\text { There is an after } \\
\text { sales service that } \\
\text { goes beyond the } \\
\text { point of purchase } \\
\text { even by the brand } \\
\text { itself that makes } \\
\text { their contacts } \\
\text { available on the } \\
\text { label of the } \\
\text { product. }\end{array}$ \\
\hline Customer Service & $\begin{array}{l}\text { In this type of product, the } \\
\text { assistance provided to the } \\
\text { customer is very } \\
\text { insignificant. }\end{array}$ & $\begin{array}{l}\text { In this type of product, the } \\
\text { assistance provided to the } \\
\text { customer is very } \\
\text { insignificant. }\end{array}$ & $\begin{array}{c}\text { Because this is a } \\
\text { more solid } \\
\text { company, it does } \\
\text { have the capacity } \\
\text { to provide } \\
\text { customer service, } \\
\text { even though it } \\
\text { faces the same } \\
\text { dilemma as the } \\
\text { others, simple use. }\end{array}$ \\
\hline
\end{tabular}

Table 5: Source of Value Purchase and Sales Environment

\begin{tabular}{|c|c|c|c|}
\hline \multicolumn{4}{|c|}{ Value Source: Purchase and Sales Environment } \\
\hline subclasses & Case 1 & Case 2 & Case 3 \\
\hline $\begin{array}{c}\text { Sales environment } \\
\text { status }\end{array}$ & $\begin{array}{l}\text { Because they do not have } \\
\text { their own space, they tend } \\
\text { to reach an agreement } \\
\text { with resellers, in the } \\
\text { general environment } \\
\text { which, to a certain extent } \\
\text { be hygienic, to provide } \\
\text { favorable surroundings for } \\
\text { the acquisition of their } \\
\text { products. }\end{array}$ & $\begin{array}{l}\text { Because they do not have } \\
\text { their own space, they tend } \\
\text { to reach an agreement } \\
\text { with resellers, in the } \\
\text { general environment } \\
\text { which, to a certain extent } \\
\text { be hygienic, to provide } \\
\text { favorable surroundings for } \\
\text { the acquisition of their } \\
\text { products. }\end{array}$ & $\begin{array}{l}\text { The environments, } \\
\text { both physical or } \\
\text { not (even if they } \\
\text { are unable to make } \\
\text { purchases), of their } \\
\text { products can be } \\
\text { found in all types } \\
\text { of surroundings } \\
\text { and, even so, be } \\
\text { consumed due to } \\
\text { the quality factor } \\
\text { and never stop } \\
\text { innovating. }\end{array}$ \\
\hline $\begin{array}{l}\text { Product displays } \\
\text { environment }\end{array}$ & $\begin{array}{l}\text { Because they are national } \\
\text { products, they tend to be } \\
\text { highlighted on displays, } \\
\text { for the sake of } \\
\text { appreciation of what is } \\
\text { national and especially } \\
\text { when well traded, because } \\
\text { they are placed in good } \\
\text { visibility of the clients, to } \\
\text { cause in them the desire } \\
\text { to buy. }\end{array}$ & $\begin{array}{l}\text { With this one the battle is } \\
\text { fiercer, because it is not } \\
\text { the only national product, } \\
\text { but it does have a } \\
\text { different concept and it is } \\
\text { conquering its space } \\
\text { compared to the others } \\
\text { and it is taking center } \\
\text { stage. }\end{array}$ & $\begin{array}{l}\text { It is already a } \\
\text { reputable brand } \\
\text { thus it has the best } \\
\text { places for the } \\
\text { products. }\end{array}$ \\
\hline
\end{tabular}

Table 6: Transfer of Ownership

\begin{tabular}{|c|c|c|c|}
\hline \multicolumn{4}{|c}{ Value Source: Transfer of ownership } \\
\hline $\begin{array}{c}\text { Payments and } \\
\text { collecting }\end{array}$ & $\begin{array}{c}\text { This is done at the place of } \\
\text { purchase }\end{array}$ & $\begin{array}{c}\text { This is done at the place of } \\
\text { purchase }\end{array}$ & $\begin{array}{c}\text { Immediately and at } \\
\text { the place of } \\
\text { purchase }\end{array}$ \\
\hline Home delivery & $\begin{array}{c}\text { They do not have this } \\
\text { service }\end{array}$ & $\begin{array}{c}\text { They do not have this } \\
\text { service }\end{array}$ & $\begin{array}{c}\text { They do have their } \\
\text { own website, but }\end{array}$ \\
\hline
\end{tabular}




\begin{tabular}{|c|c|c|c|}
\hline & & & $\begin{array}{c}\text { they do not have an } \\
\text { online sales } \\
\text { service, } \\
\text { nevertheless they } \\
\text { have home delivery } \\
\text { of customized } \\
\text { products to a niche } \\
\text { of customers. }\end{array}$ \\
\hline Merchandise Tracking & $\begin{array}{c}\text { Internally only, because } \\
\text { there are no records of } \\
\text { there being any with their } \\
\text { customers. }\end{array}$ & $\begin{array}{c}\text { Internally only, because } \\
\text { there are no records of } \\
\text { there being any with their } \\
\text { customers. }\end{array}$ & $\begin{array}{c}\text { A process with } \\
\text { weaknesses, but it } \\
\text { loss of merchandise }\end{array}$ \\
\hline Devolution & $\begin{array}{c}\text { No records, but with the } \\
\text { possibility of them being } \\
\text { produced at the point of } \\
\text { purchase. }\end{array}$ & $\begin{array}{c}\text { No records, but with the } \\
\text { possibility of them being } \\
\text { produced at the point of } \\
\text { purchase. }\end{array}$ & $\begin{array}{c}\text { This component is } \\
\text { also low, very } \\
\text { bureaucratic and } \\
\text { rarely used. }\end{array}$ \\
\hline
\end{tabular}

\section{Conclusion}

\section{Theoretical Implication}

After the use of the five sources of value of Smith and Colgate [25] to the Angolan reality, it is found that there are producers who have been taking some (still very timid) steps in this field, Three cases were analyzed: Lactiangol, Kapilongo and JMV and CAOPA, which made it possible to perceive that the studied companies have made efforts to create value through the typology of 'information' value, attained through careful packaging and labeling, transmitting a set of informative elements of several orders that reinforce the local attributes. However, the evolution in the remaining four sources of typology is unclear.

It was verified that only one company undertakes efforts to accomplish events, taking advantage of this as a vehicle of dissemination and knowledge of its products. The 'product' value source also signals some effort by betting on more advanced production systems and the final quality of the product. Regarding 'client and employee interaction', the 'ownership transfer' and the 'buying and selling' environment, there was a strong weakness due to the lack of consistent work with the distribution channels. Thus, the results indicate that in the early stages of value creation, especially those more directly related to the producer, are at the heart of the manufacturers' attention.

This is the case of the investment in product quality and manufacturing methods as well as packaging and labeling. As long as value creation starts to involve the participation of third parties, such as distributors and retailers, investment in value creation is fuzzy. This means that there is still a long way to go, whether through point-of-sale marketing, experiential marketing or even customer relationship actions.

\section{Managerial Implication}

Based on the recognition that domestic Angolan products are less valued when compared to imported products, it is clear that the way to create value in Angolan products is difficult. This implies changing minds and working closely with clients, promoting a more frequent and intense relationship with the market. For this, the companies must leave their 'comfort zone' (their factory, their products) and invest on 'following' the product to the customer. In particular, point-of-sale actions are essential if the information conveyed to the customer is to be better communicated.

The appeal to the national product and its benefits to the consumer whether they are functional or emotional is achieved through experiential actions such as events or parties, or relational actions such as coupons, contests or even customer relationship management.

\section{Further Research and Limitations}

At the academic level, it is known that Angola has a weak field of scientific research, so we hope that other researchers can also work in this area of value creation in Angola and other Lusophone African countries, and consider this study as an incentive and motivation for the dynamics of value creation 
in these markets. The results of this study can also be used by producers, entrepreneurs and public decision-makers so that there is an integrated development to the level of incentive and dynamism in the creation of value of Angolan products.

\section{References}

1. Day GS, Day GS (1990) Market driven strategy: Processes for creating value. New York: Free Press.

2. Lai AW (1995) "Consumer values, product benefits and customer value: a consumption behavior approach". ACR North American Advances.

3. Gale BT (1994) Managing Customer Value, New York: Free Press.

4. Heard Ed (1993-94), "Walking the Talk of Customer Value," National Productivity Review, 11 (Winter), 21-27.

5. Zuin LF (2006) Agronegócios: Gestão e Inovação. São Paulo: Saraiva.

6. Lepak DP, Smith KG, Taylor MS (2007) "Value creation and value capture: a multilevel perspective". Academy of management review, 32(1):180-194.

7. Lee SM, Olson DL, Trimi S (2012) "Coinnovation: convergenomics, collaboration, and co-creation for organizational values". Management Decision, 50(5):817831.

8. Gupta A, Govindarajan V (2000) "Knowledge management's social dimension: lessons from Nucor Steel", Sloan Management Review, 42(1):71-80.

9. Batra R, Ramaswamy V, Alden DL, Steenkamp JBE, Ramachander S (2000) "Effects of brand local and nonlocal origin on consumer attitudes in developing countries". Journal of consumer psychology, 9(2):83-95.

10. Las Casas AL (2006) Administração de marketing. São Paulo: Atlas.

11. Bowman C, Ambrosini V (2000) "Value creation versus value capture: towards a coherent definition of value in strategy". British Journal of Management, 11(1):115.

12. Gummerus J (2013) "Value creation processes and value outcomes in marketing theory: strangers or siblings". Marketing Theory, 13(1):19-46.
This work was carried out on the supply side, by identifying the factors that contribute to value creation in local products. However, it is always interesting to explore the demand side, identifying with Angolan consumers how the investment of national products is perceived.

13. Oliver J (2015) "The consumer's perspective on evaluating products: service is the key". Journal of Services Marketing, 29(3):200-210.

14. Cooper RG (2001) Winning at New Products, 3d ed., New York: Perseus.

15. Slater S (1997) "Developing a Customer Value-Based Theory of the Firm," Journal of the Academy of Marketing Science, 25 (2):162-167.

16. Guerrero L, Guàrdia MD, Xicola J, Verbeke W, Vanhonacker F, ZakowskaBiemans S, Scalvedi ML (2009) "Consumer-driven definition of traditional food products and innovation in traditional foods. A qualitative cross-cultural study". Appetite, 52(2):345-354.

17. Rudawska E (2014) "Customer loyalty towards traditional products-Polish market experience". British Food Journal, 116(11):1710-1725.

18. Gellynck X, Banterle A, Kühne B, Carraresi L, Stranieri S (2012) "Market orientation and marketing management of traditional food producers in the EU'. British Food Journal, 114(4):481-499.

19. Schmitz H, Nadvi K (1999) "Industrial clusters in developing countries-clustering and industrialization: Introduction". World Development, 27(9):1503-1514.

20. Malafaia GC, Barcellos JOJ (2015) "Sistemas Agroalimentares Locais e a Visão Baseada em Recursos: Construindo Vantagens Competitivas para a Carne Bovina Gaúcha”. Revista de Economia e Agronegócio, 5(1).

21. Requier-Desjardin D, F Boucher, C Cerdan (2003) Globalization, competitive advantage and evolution of productive systems. Entrepreneurship and Regional Development 15: 49-67.

22. Kühne B, Vanhonacker F, Gellynck X, Verbeke W (2010) "Innovation in traditional food products in Europe: Do sector innovation activities match 
consumers' acceptance". Food Quality and Preference, 21(6):629-638.

23. Mossberg L (2007) "A marketing approach to the tourist experience". Scandinavian journal of hospitality and tourism, 7(1):5974.

24. Park C, Whan, Bernard Jawarski, Deborah Macinnis (1986) "Strategic Brand
Concept-Image Management," Journal of Marketing, 50 (October), 135-145.

25. Smith JB, Colgate M (2014) "Customer value creation: a practical framework". Journal of marketing Theory and Practice, 15(1):7-23. 